Article

\title{
The Agency of Journalists in Competitive Authoritarian Regimes: The Case of Ukraine During Yanukovich's Presidency
}

\author{
Esther Somfalvy * and Heiko Pleines \\ Department of Politics and Economics, Research Centre for East European Studies at the University of Bremen, Germany; \\ E-Mails: somfalvy@uni-bremen.de (E.S.), pleines@uni-bremen.de (H.P.) \\ * Corresponding author
}

Submitted: 27 February 2021 | Accepted: 14 May 2021 | Published: 21 October 2021

\begin{abstract}
On the example of Ukraine during the Yanukovich presidency (2010-2014) this article explores which factors support journalists' agency in relation to censorship pressure in a competitive authoritarian regime. It shows that a critical mass of journalists existed who reacted to censorship pressure with rejection. Based, first of all, on 31 semi-structured interviews, we examine the working conditions of prominent national journalists and analyse how they describe their role and motivations. We argue that the nature of competitive authoritarianism offers journalists opportunities for critical reporting, but that it is individual characteristics of journalists-including professional ethics, networks, and job mobility-which define whether and how the respective opportunities are used.
\end{abstract}

\section{Keywords}

authoritarian regime; censorship; competitive authoritarianism; journalism; Ukraine; Yanukovich

\section{Issue}

This article is part of the issue "Media Control Revisited: Challenges, Bottom-Up Resistance, and Agency in the Digital Age" edited by Olga Dovbysh (University of Helsinki, Finland) and Esther Somfalvy (Research Centre for East European Studies at the University of Bremen, Germany).

(C) 2021 by the authors; licensee Cogitatio (Lisbon, Portugal). This article is licensed under a Creative Commons Attribution 4.0 International License (CC BY).

\section{Introduction}

Scholarly discussions of media control in non-democratic regimes often focus on the macro perspective, investigating ways of media control, like ownership or legal regulation of media. What is less studied is the agency of journalists in this context that enables them to react differently to the resulting pressure. The literature dealing with democracies offers some suggestions on possible influences that are rooted in individual journalists' profiles. According to Helmueller and Mellado (2015), role perception affects news content created by journalists, whereby role conceptions vary more between countries than within them (van Dalen et al., 2012), highlighting the importance of the country-specific context. However, in-depth studies of journalistic reaction to political pressure in a non-democratic context are largely missing beyond recent studies on self-censorship (Schimpfössl et al., 2020).

That is why we are interested in which conditions foster the agency of journalists when faced with political pressure in a competitive authoritarian regime. In this kind of regime, governments attempt to maintain the image of a functioning democracy while using a multitude of tools, including the systematic manipulation of institutions, to tilt the political "playing field" in their favour (Levitsky \& Way, 2010, p. 1). In the case of media, this leads to practices of censorship that are covert and heterogenous (Levitsky \& Way, 2010, pp. 8-9). Business people take over major mass media as part of their deals with ruling political elites; in this case, censorship pressure is exerted by media owners: a phenomenon which has been described as "media capture" (Mungiu-Pippidi, 2008; on Ukraine, see Ryabinska, 2017, pp. 59-69). In the 
case of Ukraine, for example, since the early 2000s, about two-thirds of television viewers have been watching news programmes from stations that are owned by the country's most influential business people, so-called oligarchs (Pleines, 2016, p. 124).

This analysis looks at Ukraine from 2010 to 2014, a period during which the country is considered an exemplary case of a competitive authoritarian regime (Levitsky \& Way, 2010; Pleines, 2012). The media system in Ukraine has been described as being characterized by "poverty, small size of the market, strong politicization and control of media, and low professionalism" (Dobek-Ostrowska, 2015 , p. 35). In this situation, the TV market is not driven by market logic, but rather seen as means through which to accumulate political influence (Ryabinska, 2011, p. 5). Media also depend on political advertising. For-pay political advertising in the form of so-called dzhynsa (hidden for-pay advertising) was common during the 2005-2010 election campaigns (Grynko, 2012, p. 263; Ryabinska, 2011, p. 10). These developments had affected reporting, e.g., leading to news channels ignoring facts deemed "inconvenient" for the government and an imbalance in reporting on the government compared to the opposition (Ryabinska, 2017, pp. 71-72).

Critical independent media faced selective pressure from the ruling political elites and related business networks. One example of an outlet under pressure was the television channel TVi, which lost its general broadcasting licence already in 2010, the first year of the Yanukovich presidency. In 2012 it was investigated by the tax authorities and lost access to major satellite TV distributors. Finally, in April 2013 it saw an unfriendly takeover ("Independent TV station under increasing threat," 2012). At the same time, this example demonstrates the agency of journalists. Journalists do not have to acquiesce to mounting pressure on their work by the state or oligarchic media owners. In the face of the TVi takeover, they went on strike. Later some moved on to found the independent TV channel Espreso.tv. Another prominent case was Forbes Ukraine, which had conducted an intensive investigation into state procurement systematically favouring companies allegedly close to president Yanukovich. The journal was taken over by a businessman with very close links to Yanukovich and the investigative journalists left (Tuchynska, 2013).

In sum, the conditions under which journalists in Ukraine worked were characterized by pressures on their reporting levied upon them by the political environment, including most prominently oligarchs.

\section{Reacting to Censorship Pressure on Media Under Autocracy}

Much has been written about the fact that (mostly non-democratic) governments put pressure on media and individual journalists to influence reporting (Akhrarkhodjaeva, 2017; McMillan \& Zoido, 2004). Political pressure for self-censorship is often created in violation of journalists' civil rights using violence, selective law enforcement, and manipulated charges. It is often assumed that in anticipation of potential troubles most journalists in authoritarian regimes engage in selfcensorship, meaning that they shy away from reporting on certain individuals or topics due to their anticipation of the consequences their reporting might otherwise have. In this sense, self-censorship is "often understood in relationship to censorship," as Schimpfössl et al. (2020, pp. 1-11) summarize the debate.

Pressures regarding what to report on and how to report may result in very different actions by those they target. Numerous studies on a variety of countries show that many journalists react to strong and violent pressure with wide-ranging self-censorship (Kenny \& Gross, 2008; Nadadur, 2007; Tong, 2009; Yesil, 2014). Many journalists also develop conformism and claim that they report in an appropriate way (Schimpfössl \& Yablokov, 2014). Journalists may also choose to respond with ethical justifications about why engaging in some forms of selfcensorship is appropriate (Skjerdal, 2008).

Scholarly analyses of the phenomenon are complicated by the fact that pressures are often communicated euphemistically, unlike, for example, the often cited temnyki (from temnii- "dark," directives from the presidential administration to media) of the Kuchma era in Ukraine, which provided daily instructions to journalists what (not) to cover in reporting (Grynko, 2012, p. 263). In cases where explicit censorship is absent, the "red lines" that should not be crossed when reporting are subject to interpretation and change (Fedirko, 2020; Zeveleva, 2020) so that journalists might fail to adequately anticipate the consequences of their actions. Under such conditions, journalistic self-censorship is seen as the result of the "interplay between free will, coercion and obligation" (Fedirko, 2020, p. 13).

Accordingly, the result of pressures on journalist may be something entirely different than self-censorship since journalists have agency in choosing from a large repertoire of responses to such pressures. Some journalists, while explicitly accepting some self-censorship pressure, test its limits (Lee \& Chan, 2008). Others reject such pressure outright and get into conflict with chief editors and media owners, continuing to write stories about topics that may be perceived as problematic. Furthermore, some journalists chose to resist pressure by quitting the job in protest, participating in protests, or funding independent news outlets.

What, then, enables certain journalists to resist censorship pressure and continue with critical reporting (and risk open conflict with owners or politicians)? As there is no universal framework that could be applied to the case, this study is exploratory. However, the literature on what influences media content can give some hints as to which areas to examine (Shoemaker \& Reese, 1996).

It is safe to expect that the political regime plays an important role. Self-censorship exists in democracies 
(Kohut, 2000). However, it is unique to authoritarian regimes that the content subjected to public selfcensorship pressure relates, first of all, to the performance of the political regime and its representatives, thus addressing a core issue of political media reporting. There is some literature in a political science tradition that examines the conditions under which journalists in authoritarian regimes have more or less leeway to shape media contents. The most prominent explaining factor is the overall degree of authoritarian control (Stier, 2015). Indeed, in authoritarian regimes, the pressure towards self-censorship is usually coordinated country wide. As a result, a specific bias in reporting is not restricted to an individual media outlet, but applied across major media, thus considerably reducing media pluralism.

However, it is important to note that in a competitive authoritarian regime the censorship pressure on media can strongly vary, as it is not centrally administered by a state agency. Accordingly, at the level of media organizations, we can expect a difference in pressure by media type, where TV is supposed to be most strongly controlled and the internet to offer most opportunities for pluralism (Heinrich \& Pleines, 2018, p. 5). Furthermore, we know from the Russian case that pressure from owners, transmitted via loyal editors, affects content (Fredheim, 2017) and differs in line with the position of the owners vis-à-vis the political regime.

Moreover, there are individual-level factors that influence reporting. A recent study finds that organizational factors have the largest influence on news production, while individual predispositions matter far less (for the summary of the literature see Hanitzsch et al., 2019, p. 105). However, as we are interested in more than media content production (where editorial decisions matter more), factors relating to the own professional path, personal network, or the question of how individual journalists make sense of the context they work in are as important. In this context, how journalists reflect upon their conditions and their role perception has found to have an effect on news content (Helmueller \& Mellado, 2015)

\section{Research Design}

Our analysis aims to answer the question of what enables journalists to resist to pressures of selfcensorship in a competitive authoritarian regime. As the related state of research is limited, we provide an exploratory case study examining the role of journalists working at major national media in Ukraine during the Yanukovich presidency (2010-2014). Ukraine at this time is not only a typical case of a competitive authoritarian regime, but it is also marked by a developed media system and a larger number of renowned investigative journalists. The period under study allows us to examine a consolidating competitive authoritarian regime and its crisis in the wake of the Euromaidan protests from November 2013 to February 2014.
Our exploratory case study is first of all based on 31 semi-structured interviews with Ukrainian journalists who were active during the period under study. A reputational sampling method was used to identify interviewees. With the reputational approach, we follow the strand of the literature on elite interviewing which argues for the identification of the most relevant interview partners (those with the respective reputation) instead of opting for a probability sample. Tansey (2007, p. 765), for example, states that in such cases the aim "is to obtain information about well-defined and specific events and processes, and the most appropriate sampling procedures are thus those that identify the key political actors - those who have had the most involvement with the processes of interest." To identify the key actors of relevance for a specific study, a snowball technique is often used so that the reputational approach has also been described as a different kind of snowball sampling (Farquharson, 2005).

The study presented here combines desktop research and the snowball technique to identify those prominent national journalists who had rejected censorship pressure during the Yanukovich presidency. Accordingly, our analysis describes the situation of leading national journalists, while the experience of local journalists in smaller cities was likely different. It is, thus, important to note that while Ukraine stands for many similar competitive authoritarian regimes with a media market with considerable oligarch influence, the individual journalists selected for the study do not constitute a cross-section of the profession. Our selection focuses on (often prominent) cases of independent journalists reacting with insubordination to censorship pressures and cross-references them with experiences of journalists from other groups, thus examining the conditions that enabled some to resist censorship pressure that was present throughout the system.

Questions addressed during the interviews were inspired by the literature and covered the following areas: employment history, job motivation, and journalistic neutrality. Specifically relating to their employment situation during the Yanukovich presidency, questions addressed hiring practices, work routines, the relationship between editor (owners/managers) and journalist, topics covered or difficult to cover, and self-censorship. Where applicable interviewees were asked about their experiences after an ownership change, quitting a job, or establishing a new media outlet during the period under study.

The interviews were conducted by Esther Somfalvy (Research Centre for East European Studies at the University of Bremen [FSO]) and by partners of the research project Comparing Protest Actions in Soviet and Post-Soviet Spaces, which is organized by Heiko Pleines. These partners were the Public Sociology Laboratory (PS-Lab) and the Foundation for the Preservation of the History of Maidan (FPHM), which for the interviews cooperated with the Ukrainian Institute of National Memory 
(UINP; see Kovtunovych \& Pryvalko, 2015). Interviews were conducted in English, Russian, or Ukrainian depending on the preference of the respondent. With a few exceptions, all interview partners agreed to the use of their full names in quotations. As they have a long experience of seeing their names in print (all are journalists, some are persons of public interest), they know what this agreement means. Some have explicitly objected to anonymized statements. A list of interview partners is provided in Table 1, a full documentation of the interview process has been published on the DiscussData Platform (Somfalvy \& Pleines, 2021; on DiscussData see Heinrich et al., 2019).

As the interviews were conducted after the end of the Yanukovich presidency, they are likely to contain some hindsight bias. However, as we are focusing on journalists rejecting censorship pressure, i.e., being critical of Yanukovich while he was in power, this is less of an issue. That there is no strong political bias in our interview sample is also confirmed by the fact that several respondents commented critically on the state of media freedom in the post-Maidan period. In the interviews, specific examples were usually given to substantiate more general statements. Moreover, the position of these journalists was at the time demonstrated by their public actions, e.g., writing open letters or quitting their job in protest. Still, whenever possible, we have triangulated interview statements by talking to several people from the same media outlet and by checking additional documents and media reporting at the time.

Table 1. List of interview partners.

\begin{tabular}{|c|c|c|c|c|}
\hline Interviewee & Interview by & Organization 2013 & Status 2013 & Date of interview \\
\hline Atanasov, Vitalii & FSO & Fokus & Regular author & 2019-05-14 \\
\hline Babich, Bogdana & FPHM & Spilno.tv & Co-founder & 2014-12-09 \\
\hline Berdynskykh, Kristina & FPHM & Korrespondent & Journalist, blogger & $2015-04-30$ \\
\hline Burdyga, Igor & FSO & Kommersant/Vesti Reporter & Senior business correspondent & 2019-05-14 \\
\hline Davidenko, Boris & FSO & Forbes & Editor-in-chief & 2019-05-13 \\
\hline Gumenyuk, Nataliya & FSO & Several channels & Freelancer & 2019-05-15 \\
\hline Ivanchenko, Roman & FPHM & Interfax & Journalist & $2016-10-04$ \\
\hline Kalnysh, Valerii & FSO & Kommersant & Editor-in-chief & 2019-05-17 \\
\hline Kapshuchenko, Yulia & UINP & n.a. & Journalist & $2014-10-21$ \\
\hline Kapustin, Andrey & UINP & Freelancer & Journalist, blogger & 2015-06-04 \\
\hline Karagyaur, Vladimir & FPHM & Spilno.tv & Volunteer & 2015-04-07 \\
\hline Khardy, Mar'yana & UINP & Freelancer & Photojournalist & $2014-03-21$ \\
\hline Melykh, Olga & FSO & Ukrainian Week & Communication officer & 2019-05-15 \\
\hline Nerodyk, Inna & UINP & Channel 5 & Journalist & 2014-11-06 \\
\hline Paskhover, Aleksandr & FSO & Korrespondent & Editor business & 2019-05-14 \\
\hline Petrenko, Galina & FSO & Marketing Media Review & Editor-in-chief & 2019-05-14 \\
\hline Piddubyi, Oleksandr & UINP & Freelancer & Journalist & $2014-08-22$ \\
\hline Portnikov, Vitalii & FSO & Espreso.tv & Editor-in-chief & 2019-05-17 \\
\hline Romaniuk, Roman & FSO & UNIAN & Editor news & 2019-05-17 \\
\hline Rybak, Vitalii & FSO & Local newspaper in Vynitsa & Freelancer & 2019-05-16 \\
\hline Samofalov, Andrii & FSO & Forbes Ukraine & Journalist & 2019-05-13 \\
\hline Sadomtseva, Galina & FPHM & Spilno.tv & Volunteer & 2015-07-13 \\
\hline Shara, Anatolii & FSO & Maidan media, Tyzhden & Freelancer & 2019-05-15 \\
\hline Shirochenko, Vladimir & FPHM & Freelancer & Photojournalist & 2015-04-03 \\
\hline Shovkoshitnyi, Radion & FPHM & TV channel "Business" & Journalist & $2015-05-02$ \\
\hline Sokolenko, Natal'ya & UINP & Centr-UA & Journalist & 2015-01-14 \\
\hline Yasenchuk, Aleksandr & UINP & Local media in Chernihiv & Journalist & $2014-03-20$ \\
\hline Zaklets'kii, Oleksandr & FPHM & Freelancer & Photojournalist & $2014-11-28$ \\
\hline Anonymous (No. 16) & PS-Lab & n.a. & Journalist & 2014-07-10 \\
\hline Anonymous (No. 31) & PS-Lab & n.a. & Editor & 2014-07-XX \\
\hline Anonymous (No. 48) & PS-Lab & n.a. & Journalist, blogger & $2014-07-17$ \\
\hline
\end{tabular}


A further source of information for this study is a survey on journalistic ethics and professionalism conducted in May 2013 among 52 journalists (of which 30 are from Kiev) working for print, radio, television, and internet media (Ilko Kucheriv Democratic Initiative Foundation, 2013). For a closer analysis of the context, media reports on issues relating to the media environment, media freedom and censorship have been included in the case, as well as other relevant documents, like legal acts, statements issued by agencies, and experts.

\section{Rejecting Self-Censorship Pressure in Ukraine (2010-2014)}

In order to explain the rejection of self-censorship pressure by a number of prominent national journalists in Ukraine during the Yanukovich presidency, we first present their perception of this pressure. We then go on to describe three key features of the media landscape which are associated with higher levels of journalistic agency and offered opportunities for critical reporting: namely the existence of niches, professional ethics, and a flexible job market. The period of the Euromaidan protests in 2013-2014, which was accompanied by increasing pressure on journalists, will be analysed in a separate section.

\subsection{Perception of Censorship Pressure}

The interviews support the expectation that in competitive authoritarian regimes, like Ukraine under President Yanukovich, political censorship pressure is not applied equally throughout the country and across all media. Regarding the creation of news content, there is a broad spectrum: Some respondents say they only ever experienced conflict between correspondents and editors that were part of daily reporting and had no qualms to fight for their point of view (Interview Burdyga) and could decline to report on any topic they were asked to cover (Interview Anonymous No. 16). That the exact "red lines" for reporting were not always clear is supported by the account of a journalist at Kommersant Ukraine who after an ownership change checked the fresh copies for changes made to articles and was surprised to find that none had been made (Interview Burdyga).

The majority of journalists say that they did expect some pressure from owners. Oligarchic ownership, according to Boris Davidenko, former editor-in-chief at Forbes Ukraine, often led to the creation of a list of people and topics that were not to be covered in a negative way (Interview Davidenko). Everybody in the industry, interviewees claim, knew that certain people were better left alone (Interview Romaniuk-at the time news editor at UNIAN news agency). Pressures to censor topics were sometimes quite explicit. A journalist explained that once the medium she worked at was sold, the editorial policy changed quickly and openly, as journalists "were told that the investigations related to Yanukovich, his family and team were impossible" (Interview Berdinskykh). Davidenko recalls that when Forbes was taken over by a businessman close to President Yanukovich, journalists were promised higher salaries if they stopped critical reporting and simultaneously threatened with dismissal if they did not (Interview Davidenko). At UNIAN news agency journalists were fined if they negatively covered President Yanukovich, as was made public by five former employees in an open letter in October 2012 ("Barometr svobodi slova," 2012).

While media owners often intervened systematically in the reporting of journalists, in the perception of journalists, state organs only reacted when red lines were crossed. However, writing something that was deemed "unacceptable" resulted in threats (Interview Shara). Another journalist reported having been personally followed and spied upon by secret services in 2012 while working at TVi (Interview Portnikov). These personal accounts are supported by figures from a report compiled by Reporters Without Borders ("Moment of truth," 2012) that finds systematic state violence against journalists. This violence later escalated further in the wake of the Euromaidan protests.

\subsection{Agency Based on Position, Knowing About "Niches"}

Differences in censorship pressure felt across the profession can partly be explained by the nature of the outlet and by different preferences of the owners that are-to some extent-known to journalists. One respondent described self-censorship at TV stations as "some kind of Stockholm syndrome," where it became the standard way of functioning and was no longer challenged (Interview Paskhover). There was less pressure in low-profile print publications. One editor believed that the perceived unimportance of the publication within the owner's portfolio made it possible to enjoy some freedom in their reporting (Interview Petrenko). Another interview partner reports that the pressure on the staff of Radio Vesti grew once its popularity grew (Interview Kalnysh). The interviews also support the perception that online media had more freedom. According to an interviewee:

I worked on the newspaper's website... we were a little bit disconnected, we put online news that was not much related to the newspaper-we allowed ourselves to be objective there. Journalists who worked directly on the newspaper-it was harder for them. (Interview Anonymous No. 31)

Interview partners also report on the existence of niches by topic or type of reporting. For example, an interview partner claims that investigative reporting could be done relatively unhindered (personal communication), and another one reported that business media was such a niche (Interview Burdyga). The claim about business media being a niche where reporting could be done 
relatively freely requires some context, given the structure of the Ukrainian media market with its oligarchic owners. The factor most often mentioned to explain differences in censorship pressure is, in fact, the position of the owner. This is supported by a poll of 52 journalists conducted in May 2013 in which 38 named business people with political interests as one of the biggest obstacles to press freedom, while only 27 chose ruling politicians (Ilko Kucheriv Democratic Initiative Foundation, 2013). Moreover, as owners have different interests, censorship pressure does not lead to uniform media reporting (for which in Ukraine the term "oligarchic pluralism" has been coined; Ligachova, 2015).

Another example of how ownership affects what topics are considered to be unproblematic is provided by an interview partner who recounts his experiences at a newspaper outside the capital, which was controlled by the local authorities. This meant that the actions of the national government could be criticized, while local matters had to be reported about very carefully (Interview Rybak).

Finally, it must be noted that the perceived interests of the owner and the consequences for their work are subject to journalists' interpretations. It may not even always be clear to journalists who owns their outlet (Interview Burdyga). Opaque ownership structures make it more difficult to factor in negative reactions to potentially contentious actions.

\subsection{Motivation and Professional Ethics}

Professionalism and a certain understanding of how a journalist should report-"objectively" or "neutrally" play an important part in the interviewees' role understanding. Several of them also express the belief that they would quit a job rather than compromise their integrity.

When the journalists interviewed, who were chosen for their prominent rejection of censorship pressure during the Yanukovich presidency, describe their outlook on their job, it becomes apparent that although their motivation for becoming a journalist may vary-and is often related either to chance or to a need to earn some money-at some point during their career idealism or the idea of having a societal role to play prevailed. One such perspective-changing event is described by Shara, who witnessed violence by the police during the protests on Maidan and describes it as a "bifurcation point" (Interview Shara; see also Budivska \& Orlova, 2017, p. 147).

There are different ideas about what it means to be a journalist and how "objective" or "neutral" reporting can be. However, all of our respondents highlight that journalists should follow professional standards. With that, they position themselves against any censorship pressures which they perceive as unethical. Although they use different terminology (referring to objectivity and neutrality) their ideas resemble Hanretty's (2011) con- cept of journalistic autonomy. It is also important to note that our respondents identify with different versions of "neutral" reporting, not with support for specific political camps or ideologies. It is also indicative that-although they all opposed the Yanukovich regime-many of them are also highly critical of the media freedom record of the post-Maidan government.

Some journalists self-describe as particularly driven by ideals, a fact which was known to colleagues and gave them special status (Interview Anonymous No. 31). Another journalist claims that it was clear to the new owners of her outlet that she would not write anything as a favour (Interview Berdinskykh).

As a consequence of this attitude, when the own outlet will no longer accommodate their professional standards, these journalists will quit their job and move elsewhere. During our research for this study, we have counted 13 such cases involving over 100 journalists for the period under study (Somfalvy \& Pleines, 2021). One journalist reports already having quit a well-paid job for one where he could actively oppose Kuchma in 2004 (Interview Shyrochenko). Many journalists quit without having a clear idea of where to go next (Interview Berdinskykh).

\subsection{Job Market}

The idealistic interest in working as a journalist as well as the need for some income means that the important question from the perspective of the journalists who do not fit into the pro-regime media is whether there are alternative job opportunities available, as this makes the risk of leaving or the threat of being fired less dramatic. To what extent this is the case in competitive authoritarian regimes has so far not been examined systematically. Accordingly, it is an important insight into the functioning of censorship pressures that most of our respondents who lost or quit their job during the Yanukovich presidency did not experience problems finding a new one. The Euromaidan of 2013-2014 is also reported as having provided young journalists with a window of opportunity in the job market (Interview Melykh).

Collectively, our respondents point to three explaining factors for alternative job opportunities for critical journalists within the media system:

(1) Relatively large demand for journalists in a situation of rather unattractive employment conditions. The financial situation of the media allows for little financial support for regular high-quality reporting, although some funding for investigative journalism is available (Interview Gumenyuk). Many do not stay in the profession long-term (Interview Davidenko; Interview Petrenko). Low salaries and bad working conditions also mean that journalists do not have much to lose when quitting their job.

(2) Personal networks. Recruitment for new positions is often based on pre-existing personal networks 
and recommendations. Several interview partners found jobs through friends (Interview Ivanchenko), or left their jobs together with team members and helped one another to find new employment (Interview Burdyga). Some journalists report choosing a place of work because they had friends already working there (Interview Shara). Editors may also feel responsible for their colleagues (Interview Kalnysh). In this context, it is also important to note that in Ukraine under Yanukovich seemingly there was no blacklist of journalists critical to the regime. When one of our respondents, an editor-in-chief, lost his job at a pro-Yanukovich newspaper in a conflict about reporting, he got a phone call with a job offer on the very same day, and only after he had started to work at the new media outlet did he realize that it was owned by a pro-Yanukovich oligarch, causing him to quit again (Interview Kalnysh).

(3) Opportunities to set up new media outlets. A larger number of journalists who lost or quit their job got involved in the creation of new media outlets. When Korrespondent was taken over in 2013, a whole team of journalists quit and later went on to found Novoe Vremya. Portnikov reports breaking with TVi due to their refusal to report on the Euromaidan protests (Interview Portnikov). He set up Espreso.tv with a team largely made up of former TVi employees in November 2013. Similarly, Bogdana Babich and her team set up Spilno.tv which provided live broadcasts from the protests. Other journalist-driven projects were Hromadske.TV and Channel 112. That this was possible is due to the nature of competitive authoritarianism which formally guarantees media freedom, and factually only restricts it when it challenges the ruling elites, which small start-up media at least initially did not do.

As discussed in the section on the research design this study focuses on prominent journalists working for national media. Clearly, the opportunities outlined above are not available to all journalists. Most importantly, the media landscape outside the capital is usually much less varied, so that job mobility may simply not be feasible due to the lack of job offers. Moreover, regional media were in many cases under stricter and more unified control either by the regional state administration or one dominating oligarch than national ones.

However, even for prominent journalists this relative job mobility only exists as long as there are niche publications accommodating journalist who offend the regime, and an official blacklist of journalists does not exist. This started to change during the later stage of the Yanukovich presidency, as we will discuss in the following section.

\section{The Euromaidan Protests}

The beginning of the protests in late November 2013 on the Maidan Nezalezhnosti, a central square in Kiev, in response to the announcement that the government would not, as anticipated, sign an association agreement with the European Union (which is why the protests were later referred to as "Euromaidan") took place during a time of growing concern for the future of independent media.

Ukrainian journalists in 2013 felt a tightening grip of Yanukovich's associates on media. Journalists recall that in 2013 the space for independent journalism was rapidly shrinking, as a "big shopping" of media assets was going on among oligarchs (Interview Kapustin). This prompted some to fear that if nothing changed, soon there would be no space for independent reporting left, and some journalists were already prepared to switch profession or leave the country (Interview Anonymous No. 48). Paskhover, business editor at Korrespondent magazine at that time, recalls a meeting in November 2013 where together with a colleague they announced that they wanted to quit over the new editorial policy:

When we said that we would leave, we were honestly told that there would be nowhere to go soon. They were going to buy everything. It was the first time I thought about changing my profession. I just really had the feeling that, in general, there would be nowhere to go professionally. Well, and then two weeks later Maidan happened.

A substantial number of journalists was present at and participating in the protests from the start. This was partially because the initial call for protest was a post on Facebook by Mustafa Nayyem, a journalist who addressed his friends and colleagues. Journalists mentioned as the reason for initially going to Maidan their ties to the organizers (Interview Babich; Interview Kapustin), or "sociological curiosity" (Interview Berdinskykh) about the unfolding events. As the protests gained momentum, more journalist recognized their magnitude and expressed a feeling that this was simply the place they had to be (Interview Khardy; Interview Piddubyi). Professional networks seem to play a role in whether journalists went to the protests at the early stage. A network of like-minded colleagues already existed through their involvement in the Stop Censorship! movement founded in 2010 (Budivska \& Orlova, 2017, p. 140).

The protests received little attention from stateowned media at the beginning and were covered mostly by small independent media (including online TV channels that became popular due to this coverage). Initially, there was relative freedom to report on the events, which is often attributed to the fact that the oligarchs owning the majority of the media did not take a side, which left editors and journalist to decide for themselves 
how to cover the events and whether to participate in the protests (for a detailed account of how reporting changed throughout the events see Ryabinska, 2015; Szostek, 2014). When protests grew in size, journalists working at some pro-Yanukovich media were not allowed to cover them, but apart from that were left to their own devices. A journalist working at a TV channel linked to Yanukovich, the channel Business, recounts his experience:

In the middle of the Maidan [protests], we were broadcasting "Swan Lake" non-stop. We'd come to work, but we didn't do the news. On the one hand, it's good that you're not on vacation and you get paid. At this time, instead, you could have gone to Maidan in peace. On the other hand, you should show up for work, but you're not working. (Interview Shovkoshytnyi; similarly Interview Anonymous No. 31).

The situation for freelancers was different. While they could simply decide to go to Maidan (Interview Pidduby), freelancers could have difficulty proving they were there on an assignment and could be prosecuted for participation in a riot. The consequence, as one interviewee explains, was the blurring of the line between those participating as citizens, as journalists, or as combatants (Interview Zaklets'kii).

The Euromaidan protests brought increasing repression, including physical violence, some specifically targeting journalists and opposition media ("Raids on three opposition media," 2013). Another catalytic moment came in January 2014, when the parliament passed repressive media legislation. Galina Petrenko who during that time was the editor-in-chief of a marketing publication recounts that she and her colleagues were discussing how to react-either by publishing an issue containing only white pages or by writing about the issue. The decision to write was taken with a feeling of "while we can still talk, well, until the law comes into force, we have to talk. Our job is to talk. Well, that's why we talked as much as we could" (Interview Petrenko).

Regardless of whether they started attending the protests in a journalistic capacity or as activists, many interviewees say that they attempted to keep these roles separate. They did this by separating between day-job covering the events and activism in their spare time (Interview Ivanchenko). In many instances, this proved impossible as the events unfolded-just as suggested by the literature that finds a blurring of boundaries between journalism and activism (Ligachova, 2015; Szostek, 2014). For example, one journalist also explains that only later did she and her colleagues realize that they were already engaged in activism beyond their purely journalistic work (Interview Petrenko).

\section{Conclusion}

The research presented in this article examines what enabled a group of Ukrainian journalists to reject cen- sorship pressure and exercise agency over their reporting. The case study demonstrates that a critical mass of journalists existed under competitive authoritarianism in Ukraine who rejected censorship pressure.

It can be stated that the dispersed control over media assets that is typical for competitive authoritarian regimes, and which in the case of Ukraine is exercised by oligarchs, is an important element of what could be described as opportunities for critical journalism. The diverse strategies of media owners-with additional differentiation by media type and visibility-can explain why journalists are exposed to different levels of self-censorship pressure, which means that niches for critical reporting exist. A second important element of the opportunities for critical journalism is the high degree of job mobility, often based on professional networks. Journalists were also sharing the perception that they knew about the rules and niches where they could report according to their standards, switching jobs if they felt their professional ethics compromised. Importantly, related job mobility was not hampered by any coordinated blacklisting of critical journalists. A third element of the opportunities for critical reporting is the possibility to register and organise independent media outlets. All of these elements facilitated the agency of journalists under the competitive authoritarian regime established by Yanukovich.

The opportunities are thus dependent on having some media pluralism in place. The perception that this pluralism was being threatened by the Yanukovich regime was also shared by many interviewees. This may have contributed to mobilization as the Euromaidan protests started in late 2013, as journalists were facing the question of how to position themselves vis-à-vis the regime. Russia in the last two decades serves an illustrative case of what happens when a regime obtains control over a large proportion of the media sphere, which by itself is a sign of the regime becoming fully authoritarian (Pleines, 2020; Somfalvy, 2020).

The journalists who used the opportunities for critical journalism were all driven by professional ethics focusing on journalistic autonomy. That this was not about empty words was proven by several mass resignations of entire journalistic teams in the years 2012-2013. Such collective action also points to another important factor explaining critical journalism - the embeddedness in networks of like-minded colleagues. This was relevant not only for job security but also for joint projects like the foundation of new media outlets and joint activism.

These findings on journalists under authoritarianism resonate with the literature on other professions' agency, which is linked to their motivation for the rejection of authoritarian control and collective action. For example, studies on lawyers suggest that professional ethics and encountering the violation of rights might foster mobilization against an authoritarian regime (Kazun \& Yakovlev, 2017). On the other hand, lawyers rely on state structures to a higher degree than 
journalists, who might also be more mobile. This suggests that journalists could, by nature of their profession, have more agency than lawyers when working under competitive authoritarianism. Hence, a comparison with how other professions resist authoritarianism could foster a broader understanding of how individuals function within and make use of opportunity structures their profession provides based on how it relates to the wider regime's context.

\section{Acknowledgments}

This article has been produced as part of the research project Media Control as Source of Political Power: The Role of Oligarchs in Electoral Authoritarian Regimes, which is conducted by the Research Centre for East European Studies at the University of Bremen and receives financial support from the Deutsche Forschungsgemeinschaft (DFG) - grant No. 391270526. Additional interviews included in the analysis presented here have been conducted as part of the research project Comparing Protest Actions in Soviet and PostSoviet Spaces, which is organized by Heiko Pleines at the Research Centre for East European Studies at the University of Bremen with financial support from the Volkswagen Foundation.

\section{Conflict of Interests}

The authors declare no conflict of interests.

\section{References}

Akhrarkhodjaeva, N. (2017). The instrumentalisation of mass media in electoral authoritarian regimes: Evidence from Russia's presidential election campaigns of 2000 and 2008. Ibidem.

Barometr svobodi slova za zhovten 2012 roku [Freedom of speech barometer for October 2012]. (2012, November 7). Institute for Mass Information. https://imi.org.ua/monitorings/barometr-svobodislova-za-jovten-2012-roku

Budivska, H., \& Orlova, D. (2017). Between professionalism and activism: Ukrainian journalism after the Euromaidan. Kyiv-Mohyla Law and Politics Journal, 3, 137-156. https://doi.org/10.18523/kmlpj120120. 2017-3.137-156

Dobek-Ostrowska, B. (2015). 25 years after communism: Four models of media and politics in Central and Eastern Europe. In B. Dobek-Ostrowska \& M. Glowacki (Eds.), Democracy and media in Central and Eastern Europe 25 years on (pp. 11-46). Peter Lang.

Farquharson, K. (2005). A different kind of snowball: Identifying key policymakers. International Journal of Social Research Methodology, 8(4), 345-353. https:// doi.org/10.1080/1364557042000203116

Fedirko, T. (2020). Self-censorships in Ukraine: Distinguishing between the silences of television jour- nalism. European Journal of Communication, 35(1), 12-28. https://doi.org/10.1177/0267323119897424

Fredheim, R. (2017). The loyal editor effect: Russian online journalism after independence. PostSoviet Affairs, 33(1), 34-48. https://doi.org/10.1080/ 1060586X.2016.1200797

Grynko, A. (2012). Ukrainian journalists' perceptions of unethical practices: Codes and everyday ethics. Central European Journal of Communication, 2(5), 259-274.

Hanitzsch, T., Hanusch, T., Ramaprasad, J., \& de Beer, A. S. (Eds.). (2019). Worlds of journalism: Journalistic cultures around the globe. Columbia University Press.

Hanretty, C. (2011). Public broadcasting and political interference. Routledge.

Heinrich, A., Herrmann, F., \& Pleines, H. (2019). Transparency and quality assessment of research data in post-Soviet area studies: The potential of an interactive online platform. Journal of Eurasian Studies, 10(2), 136-146. https://doi.org/10.1177/ 1879366519850698

Heinrich, A., \& Pleines, H. (2018). The meaning of "limited pluralism" in media reporting under authoritarian rule. Politics and Governance, 6(2), 103-111. https://doi.org/10.17645/pag.v6i2.1238

Helmueller, L., \& Mellado, C. (2015). Professional roles and news construction: A media sociology conceptualization of journalists' role conception and performance. Communication and Society, 28(3), 1-11.

Ilko Kucheriv Democratic Initiative Foundation. (2013, June 5). Svoboda slova v Ukraini: Zagal'nonacional'ne $i$ ekspertne opitovannia [Freedom of speech in Ukraine: A nation-wide expert survey]. https:// dif.org.ua/en/article/svoboda-slova-v-ukrainizagalnonatsionalne-y-ekspertne-opituvannya

Independent TV station under increasing threat. (2012, September 7). Reporters Without Borders. https://rsf.org/en/news/independent-tv-stationunder-increasing-threat

Kazun, A., \& Yakovlev, A. (2017). Who demands collective action in an imperfect institutional environment? A case study of the profession of advocates in Russia. Journal of Eurasian Studies, 8(1), 60-71. https:// doi.org/10.1016/j.euras.2016.08.001

Kenny, T., \& Gross, P. (2008). Journalism in Central Asia: A victim of politics, economics, and widespread self-censorship. The International Journal of Press/Politics, 13(4), 515-525. https://doi.org/ 10.1177/1940161208324644

Kohut, A. (2000). Self-censorship: Counting the ways. Columbia Journalism Review, 39(1), 42-43.

Kovtunovych, T., \& Pryvalko, T. (2015). Maidan vid pershiyi osoby: 45 Istorii Revolyuciyi hidnosti [Firstperson Maidan: 45 stories of the Revolution of Dignity]. Ukrainian Institute of National Memory.

Lee, F., \& Chan, J. (2008). Organizational production of self-censorship in the Hong Kong media. The International Journal of Press/Politics, 14(1), 112-133. 
https://doi.org/10.1177/1940161208326598

Levitsky, S., \& Way, L. A. (2010). Competitive authoritarianism: Hybrid regimes after the Cold War. Cambridge University Press.

Ligachova, N. (2015, April 20). Media oboz ili media avangard? [Media bandwagon or media avant-garde]? MediaSapiens. http://osvita.mediasapiens.ua/ trends/1411978127/mediaoboz_ili_mediaavangard

McMillan, J., \& Zoido, P. (2004). How to subvert democracy: Montesins in Peru. Journal of Economic Perspectives, 18(4), 69-92.

Moment of truth for freedom of information, concern on eve of elections. (2012, October 24). Reporters Without Borders. https://rsf.org/en/news/momenttruth-freedom-information-concern-eve-elections

Mungiu-Pippidi, A. (2008). How media and politics shape each other in the new Europe. In K. Jakubowicz \& M. Sukosd (Eds.), Finding the right place on the map: Central and Eastern European media change in a global perspective (pp. 87-100). Intellect.

Nadadur, R. D. (2007). Self-censorship in the Pakistani print media. South Asian Survey, 14(1), 45-63. https://doi.org/10.1177/097152310701400105

Pleines, H. (2012). From competitive authoritarianism to defective democracy. Political regimes in Ukraine before and after the Orange Revolution. In S. Stewart, M. Klein, A. Schmitz, \& H. Schröder (Eds.), Presidents, oligarchs, and bureaucrats: Forms of rule in the postSoviet space (pp. 125-138). Ashgate.

Pleines, H. (2016). Oligarchs and politics in Ukraine. Demokratizatsiya, 24(1), 105-127.

Pleines, H. (2020). Media control as source of political power: Differentiating reach and impact. Russian Analytical Digest, 258, 2-7.

Raids on three opposition media as pro-European protests dispersed. (2013, December 9). Reporters Without Borders. https://rsf.org/en/news/raidsthree-opposition-media-pro-european-protestsdispersed

Ryabinska, N. (2011). The media market and media ownership in post-communist Ukraine. Problems of PostCommunism, 58(6), 3-20. https://doi.org/10.2753/ PPC1075-8216580601

Ryabinska, N. (2015). Ukraine: Local media on the Euromaidan protests. Cultures of History Forum, 2015. https://doi.org/10.25626/0031

Ryabinska, N. (2017). Ukraine's post-communist mass media: Between capture and commercialization. Ibidem.

Schimpfössl, E., \& Yablokov, I. (2014). Coercion or conformism? Censorship and self-censorship among Russian media personalities and reporters in the 2010s. Demokratizatsiya, 22(2), 295-311.
Schimpfössl, E., Yablokov, I., Zeveleva, O., Fedirko, T., \& Bajomi-Lazar, P. (2020). Self-censorship narrated: Journalism in Central and Eastern Europe. European Journal of Communication, 35(1), 3-11. https://doi. org/10.1177/0267323119897801

Shoemaker, P., \& Reese, S. (1996). Mediating the message: Theories of influence on mass media content. Longman.

Skjerdal, T. S. (2008). Self-censorship among news journalists in the Ethiopian state media. African Communication Research, 1(2), 185-206.

Somfalvy, E. (2020). Shrinking niches for independent journalism: The case of Vedomosti. Russian Analytical Digest, 258, 8-11.

Somfalvy, E., \& Pleines, H. (2021). Data collection for Journalists in competitive authoritarian regimes. The case of Ukraine 2010-2014, v. 1.0 [Data set]. Discuss Data. https://discuss-data.net/dataset/ 9211b92e-a806-4e6c-ad75-d031a910b9f1

Stier, S. (2015). Democracy, autocracy, and the news: The impact of regime type on media freedom. Democratization, 22(7), 1273-1295. https://doi.org/10.1080/ 13510347.2014.964643

Szostek, J. (2014). The media battles of Ukraine's Euromaidan. Digital Icons, 2014(11), 1-19. http://www. digitalicons.org/issue11/the-media-battles-ofukraines-euromaidan

Tansey, O. (2007). Process tracing and elite interviewing: A case for non-probability sampling. PS: Political Science \& Politics, 40(4), 765-772.

Tong, J. (2009). Press self-censorship in China: A case study in the transformation of discourse. Discourse \& Society, 20(5), 593-612. https://doi.org/10.1177/ 0957926509106412

Tuchynska, S. (2013, August 8). Journalists to leave Forbes in protest over new owner. Kyiv Post. https:// www.kyivpost.com/article/content/ukraine-politics/ journalists-to-leave-forbes-in-protest-over-newowner-327912.html

van Dalen, A., de Vreese, C., \& Albæk, E. (2012). Different roles, different content? A four-country comparison of the role conceptions and reporting style of political journalists. Journalism, 13(7), 903-922. https://doi.org/10.1177/1464884911431538

Yesil, B. (2014). Press censorship in Turkey: Networks of state power, commercial pressures, and selfcensorship. Communication, Culture, and Critique, 7(2), 154-173. https://doi.org/10.1111/cccr.12049

Zeveleva, O. (2020). Towards a bourdieusian sociology of self-censorship: What we can learn from journalists adapting to rapid political change in Crimea after 2014. European Journal of Communication, 35(1), 46-59. https://doi.org/10.1177/0267323119897798 


\section{About the Authors}

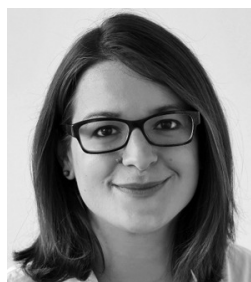

Esther Somfalvy is a research fellow at the at the Research Centre for East European Studies at the University of Bremen. Her research interests include comparative authoritarianism studies, political institutions (parliaments, elections), and media.

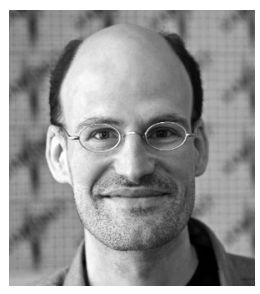

Heiko Pleines is head of the Department of Politics and Economics, Research Centre for East European Studies at the University of Bremen and professor of comparative politics at the University of Bremen. His research focuses on the functioning of authoritarian regimes in the post-Soviet region, including prominently the role of mass media. 